\title{
SISTEM PENDUKUNG KEPUTUSAN DALAM MENENTUKAN BEASISWA BERPRESTASI MENGGUNAKAN METODE FUZZY (STUDI KASUS: INSTANSI XYZ)
}

\author{
Dimas Wahyu Wibowo', Eka Larasati Amalia ${ }^{2}$ \\ 1,2 Teknik Informatika, Politeknik Negeri malang \\ 1,2dimaswahyuwibowoster@gmail.com, ekalarasati.a@gmail.com
}

\begin{abstract}
Abstrak- Beasiswa adalah bantuan keuangan yang diberikan kepada perorangan untuk keberlangsungan pendidikan yang ditempuh. Penentuan penerima beasiswa yang dilakukan Instansi XYZ saat ini masih bersifat manual. Hal ini tentu memerlukan waktu yang lama dan tingkat akurasi yang rendah. Sistem Pendukung Keputusan ini mampu membantu memudahkan dalam menentukan mahasiswa yang layak mendapatkan beasiswa secara tepat dan cepat. Penggunaan metode Fuzzy dalam sistem pendukung keputusan dilakukan dengan cara melakukan pembobotan pada setiap kriteria yang dijadikan dasar dalam penentuan penerimaan beasiswa.
\end{abstract}

Kata kunci : Beasiswa, Sistem Pendukung Keputusan, Fuzzy.

\section{Pendahuluan}

Instansi XYZ setiap tahunnya memberikan beasiswa kepada mahasiswa yang layak untuk mendapatkannya. Sesuai dengan peraturan yang telah ditetapkan oleh Instansi XYZ untuk memperoleh beasiswa, maka diperlukan kriteria-kriteria untuk menentukan mahasiswa yang terpilih sebagai penerima beasiswa. Penentuan penerima beasiswa yang dilakukan Instansi XYZ saat ini masih bersifat manual. Bagian akademik mengurutkan siswa per kriteria, kemudian menentukan penerima beasiswa. Hal ini tentu memerlukan waktu yang lama dan tingkat akurasi yang rendah. Karena dimungkinkan adanya pengamatan kriteria calon penerima yang terlewat. Untuk membantu mengatasi masalah tersebut maka diperlukan sebuah sistem pendukung keputusan dalam menentukan penerima beasiswa bagi mahasiswa yang berprestasi menggunakan metode Fuzzy. 


\section{Tinjauan Pustaka}

\section{A. Sistem Pendukung Keputusan (SPK)}

Menurut Turban Sistem Pendukung Keputusan (SPK) atau Decision Support System (DSS) adalah sebuah sistem yang dapat memecahkan masalah dengan kondisi semi terstruktur dan tak terstruktur (Turban, 2005:1). SPK dapat membantu memberikan penilaian terhadap alternatif dalam pengambilan keputusan. Proses pengambilan keputusan terdiri dari tiga fase proses, yaitu:

- Fase intelligence atau studi kelayakan, dalam tahap ini dilakukan proses identifikasi masalah

- Fase design atau perancangan, dalam tahap ini memformulasikan model yang akan digunakan dan menentukan kriteria.

- Fase choice atau pemilihan, dalam tahap ini didapatkan keluaran berupa solusi permasalahan.

Sistem Pendukung Keputusan terdiri dari tiga komponen utama yaitu:

- Subsistem data, merupakan komponen penyedia data yang diperlukan oleh sistem.

- Subsistem model, merupakan komponen yang mengubah data menjadi sebuah informasi yang berguna bagi sistem.

- Antarmuka pengguna, komponen ini berfungsi sebagai sarana interaksi antara user dengan sistem.

\section{B. Logika Fuzzy}

Logika Fuzzy pertama kali diperkenalkan oleh Prof. Lotfi A. Zadeh pada tahun 1965. Dasar logika fuzzy adalah teori himpunan fuzzy. Peranan derajat keanggotaan pada teori himpunan fuzzy sebagai penentu keberadaan elemen dalam suatu himpunan. Nilai keanggotaan atau derajat keanggotaan atau membership function menjadi ciri utama dari penalaran dengan logika fuzzy tersebut.

Fuzzy memiliki 3 bagian, yaitu fuzzifikasi, inferensi fuzzy, dan defuzzifikasi. Fuzzifikasi adalah proses untuk mengubah input sistem yang mempunyai nilai tegas menjadi variabel linguistik menggunakan fungsi keanggotaan yang disimpan dalam basis pengetahuan fuzzy. Inferensi fuzzy adalah proses untuk mengubah input fuzzy menjadi output fuzzy dengan cara mengikuti aturan-aturan (IF-THEN Rule) yang telah ditetapkan pada basis pengetahuan. Defuzzifikasi adalah proses mengubah output fuzzy yang diperoleh dari mesin inferensi menjadi nilai tegas menggunakan fungsi keanggotaan yang sesuai dengan saat dilakukan fuzzifikasi.

Ada beberapa fungsi keanggotaan himpunan fuzzy, antara lain fungsi keanggotaan linier, fungsi keanggotaan segitiga, dan fungsi keanggotaan trapesium.

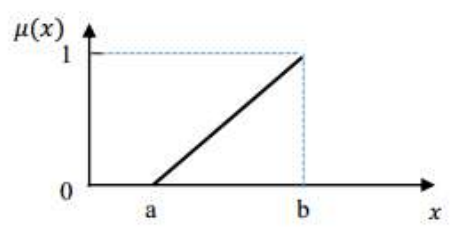

$$
\mu(x)\left\{\begin{array}{cc}
0 ; & \text { jika } x \leq a \\
\frac{(x-a)}{(b-a)} ; & \text { jika } a \leq x \leq b \\
1 ; & \text { jika } x \geq b
\end{array}\right.
$$

Antivirus: Jurnal Ilmiah dan Teknik Informatika, Mei 2017, Vol.11, No. 1

Gambar 1. Grafik fungsi keanggotaan himpunan representasi linear naik 


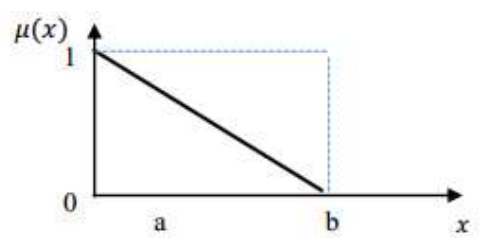

$$
\mu(x)\left\{\begin{array}{c}
\frac{(x-a)}{(b-a)} ; \text { jika } a \leq x \leq b \\
0 ; \quad \text { jika } x \geq b
\end{array}\right.
$$

Gambar 2. Grafik fungsi keanggotaan himpunan representasi linear turun

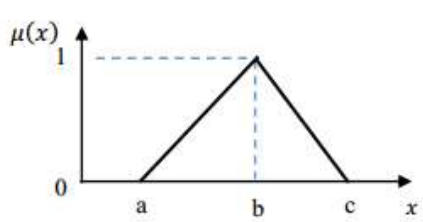

$$
\mu(x)\left\{\begin{array}{l}
0 ; \text { jika } x \leq \text { a atau } x \leq c \\
\frac{(x-a)}{(b-a)} ; \text { jika } a<x \leq b \\
\frac{(c-x)}{(c-b)} ; \text { jika } b<x<c
\end{array}\right.
$$

Gambar 3. Grafik fungsi keanggotaan himpunan representasi keanggotaan segitiga

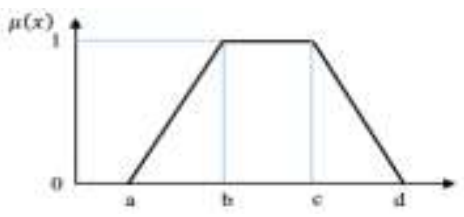

$$
\mu(x)\left\{\begin{array}{c}
0 ; j i k a x \leq a \text { atan } x \geq d \\
\frac{(x-a)}{(b-a)} ; j i k a d a<x \leq b \\
\frac{(c-x)}{(c-b)} ; j \text { jika } c<x<d \\
1 ; \text { jika } b<x \leq d
\end{array}\right.
$$

Gambar 4. Grafik fungsi keanggotaan himpunan fuzzy representasi keanggotaan trapesium

\section{Metode Penelitian}

\section{A. Desain Sistem}

\section{Analisa Kebutuhan Sistem}

Pada sistem ini, user dapat memasukan sendiri masukan data masing-masing parameter sesuai dengan range yang telah disediakan oleh sistem. Sistem akan memproses data input untuk dikelompokan sesuai fungsi keanggotaan dan rule yang telah ditentukan.

a. Kebutuhan Input

Kebutuhan input sistem terdiri dari: nilai IPK, penghasilan kotor orangtua, dan prestasi non akademik.

b. Kebutuhan Output

Output sistem berupa rekomendasi nama mahasiswa yang berhak mendapatkan beasiswa.

\section{Data Flow Diagram}

Data Flow Diagram menggambarkan aliran data yang terjadi di dalam sistem, sehingga dengan dibuatnya DFD ini akan terlihat arus data yang mengalir dalam sistem. 


\subsection{Konteks Diagram}

Diagram konteks sistem terlihat pada Gambar 5 di bawah ini.

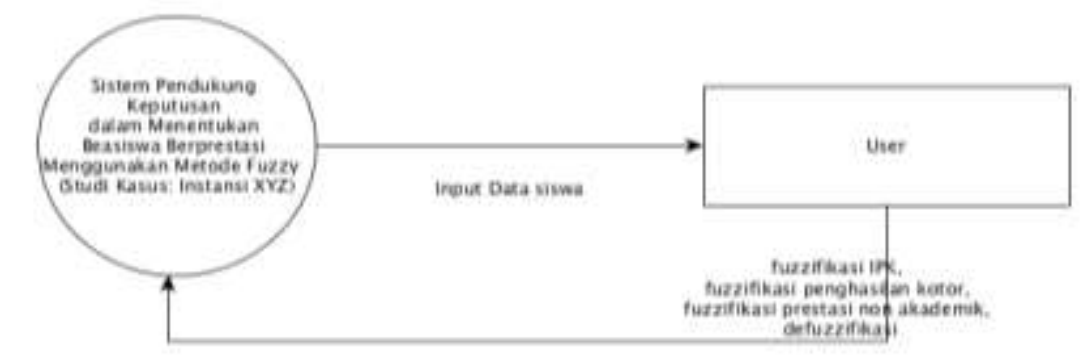

Gambar 5. Diagram Konteks

Dari diagram konteks sistem di atas dapat dilihat terdapat satu entitas yang terhubung dalam sistem ini, yaitu bagian akademik yang selanjutnya disebut user. User yang memasukkan data berupa nama mahasiswa, nilai IPK, penghasilan kotor orangtua, dan prestasi yang diperoleh. Setelah masukan diproses dalam sistem fuzzy, maka dapat diperoleh hasil rekomendasi nama mahasiswa yang berhak menerima beasiswa.

\section{Konsep Pembentukan Database}

Pembentukan database ini mempunyai dua table yaitu tb_kriteria, tb_siswa. Pada tabel tb_kriteria digunakan untuk menyimpan data kriteria.

Pada tabel tb_siswa digunakan untuk menyimpan data alternatif mahasiswa penerima beasiswa.

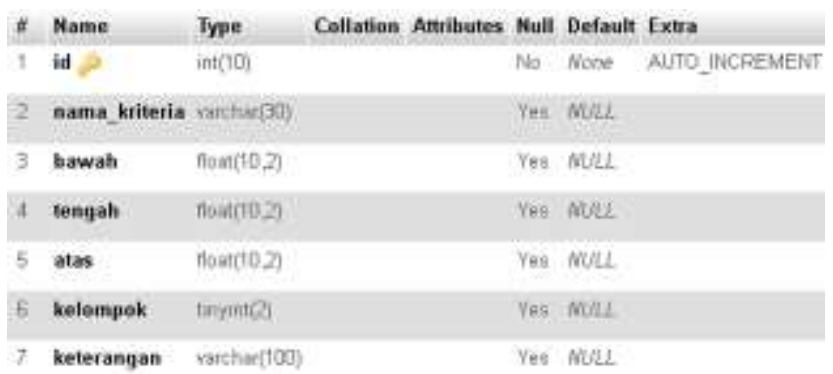

Gambar 6. Struktur Tabel tb_kriteria 


\begin{tabular}{|c|c|c|c|c|c|c|}
\hline \# & Name & Type & Collation Attributes & Null & Default & Extra \\
\hline 1 & id 2 & $\operatorname{int}(5)$ & & No & None & AUTO_INCREMENT \\
\hline 2 & nip & $\operatorname{varchar(5)}$ & & Yes & MULL & \\
\hline 3 & nama & varchar(25) & & Yes & NULL & \\
\hline 4 & IPK & $\operatorname{int}(5)$ & & Yes & MULL & \\
\hline 5 & Penghasilan_Kotor & $\operatorname{int}(5)$ & & Yes & NULL & \\
\hline 6 & Prestasi_non_akademik & $\operatorname{int}(5)$ & & Yes & MULL & \\
\hline
\end{tabular}

Gambar 7. Struktur Tabel tb_siswa

\section{Fungsi Derajat Keanggotaan}

Tabel 1. Data Mahasiswa

\begin{tabular}{|c|c|c|c|c|}
\hline Nip & Nama & IPK & $\begin{array}{c}\text { Penghasilan } \\
\text { Kotor }\end{array}$ & $\begin{array}{c}\text { Prestasi } \\
\text { non } \\
\text { Akademik }\end{array}$ \\
\hline 164122 & $\begin{array}{l}\text { Ade } \\
\text { Saputra }\end{array}$ & 75 & 80 & 60 \\
\hline 164135 & $\begin{array}{l}\text { Aditio } \\
\text { Rahmat }\end{array}$ & 77 & 88 & 55 \\
\hline 164140 & $\begin{array}{l}\text { Afina } \\
\text { Aksari }\end{array}$ & 45 & 63 & 54 \\
\hline 164101 & $\begin{array}{l}\text { Annina } \\
\text { Avelia }\end{array}$ & 67 & 77 & 50 \\
\hline 164130 & $\begin{array}{l}\text { Aprilia } \\
\text { Rani }\end{array}$ & 90 & 60 & 65 \\
\hline 164190 & $\begin{array}{l}\text { Bagus } \\
\text { Krisna }\end{array}$ & 90 & 90 & 90 \\
\hline 164105 & $\begin{array}{l}\text { Indah } \\
\text { Nurhayati }\end{array}$ & 90 & 70 & 65 \\
\hline 164143 & $\begin{array}{l}\text { Jenar } \\
\text { Trhapsari }\end{array}$ & 45 & 60 & 70 \\
\hline 164160 & $\begin{array}{l}\text { Rahmad } \\
\text { Tomi }\end{array}$ & 70 & 30 & 35 \\
\hline 164133 & $\begin{array}{c}\text { Tommy } \\
\text { Ardiansah }\end{array}$ & 60 & 50 & 80 \\
\hline
\end{tabular}


Pada fungsi derajat keanggotaan menggunakan fuzzy dibagi menjadi keanggotaan IPK, penghasilan kotor orangtua, dan prestasi yang diperoleh.

Tabel 2. Pengelompokan IPK

\begin{tabular}{cccc}
\hline Variabel & $\begin{array}{c}\text { Himpunan } \\
\text { Fuzzy }\end{array}$ & $\begin{array}{c}\text { Range } \\
\text { IPK (x) }\end{array}$ & $\begin{array}{c}\text { Domain } \\
\text { Nilai }\end{array}$ \\
\hline IPK & Kurang & $2.5-2.74$ & $0-65$ \\
& Cukup & $2.75-3.6$ & $54-80$ \\
& Tinggi & $3.5-4.0$ & $65-100$ \\
\hline
\end{tabular}

Fungsi keanggotaan untuk variabel IPK terdiri dari tiga himpunan fuzzy yaitu Kurang, Cukup, dan tinggi yang diambarkan dalam kurva segitiga seperti gambar 8 .

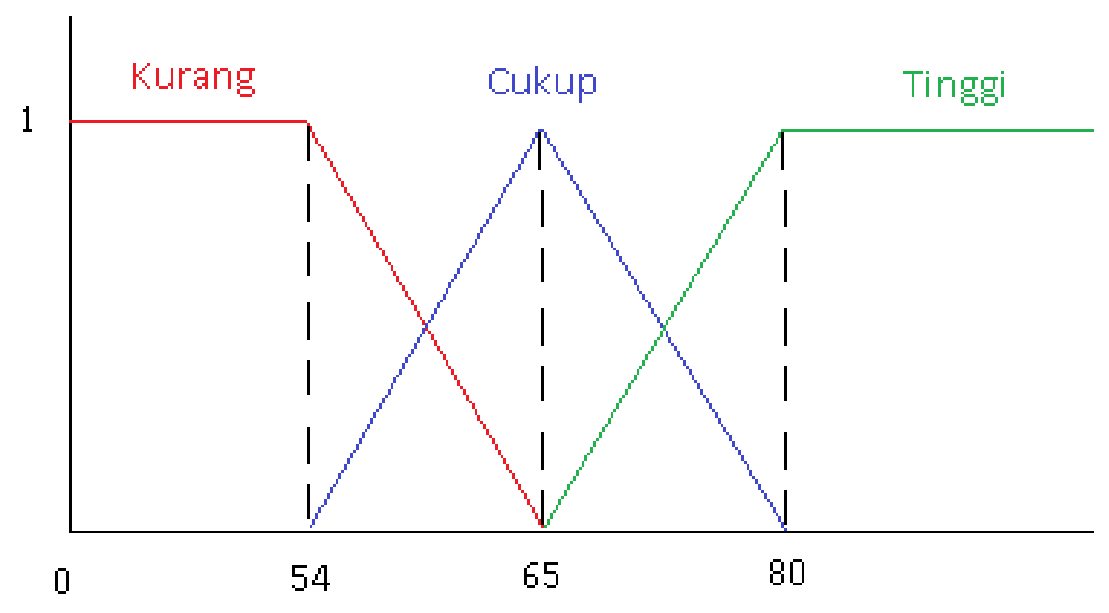

Gambar 8. Grafik Fungsi Keanggotaan IPK

Fungsi keanggotaan:

$$
\begin{aligned}
& \mu \text { Kurang }[\mathrm{x}]=\left\{\begin{aligned}
1, & x \leq 54 \\
\frac{65-x}{65-54}, & 54<x<65 \\
0, & x \geq 65
\end{aligned}\right. \\
& \mu \text { Cukup }[\mathrm{x}]=\left\{\begin{aligned}
0, & x<65 \\
\frac{x-65}{80-65}, & 65<x<80 \\
1, & x \geq 80 \\
0, & x<65
\end{aligned}\right. \\
& \mu \text { Tinggi }[\mathrm{x}]=\left\{\begin{aligned}
& x-65 \\
& \frac{x-65}{80-6}, 65<x<80 \\
& 1, x \geq 80
\end{aligned}\right.
\end{aligned}
$$


Tabel 3. Pengelompokan Penghasilan Kotor Orangtua

\begin{tabular}{lccc}
\hline \multicolumn{1}{c}{ Variabel } & $\begin{array}{c}\text { Himpunan } \\
\text { Fuzzy }\end{array}$ & $\begin{array}{c}\text { Range } \\
\text { Peghasilan } \\
\text { kotor orangtua } \\
(\mathrm{x})\end{array}$ & $\begin{array}{c}\text { Domain } \\
\text { Nilai }\end{array}$ \\
\hline $\begin{array}{l}\text { Penghasilan } \\
\text { kotor } \\
\text { orangtua }\end{array}$ & Kurang & $1.250 .000<\mathrm{x}$ & $0-65$ \\
& & $<1.750 .000$ & \\
& Cukup & $750.000<\mathrm{x}<$ & $54-80$ \\
& & 1.250 .000 & \\
& Tinggi & $\mathrm{x}<750.000$ & $65-100$ \\
\hline
\end{tabular}

Fungsi keanggotaan untuk variabel penghasilan kotor terdiri dari tiga himpunan fuzzy yaitu Kurang, Cukup, dan Tinggi yang diambarkan dalam kurva segitiga sebagai berikut:

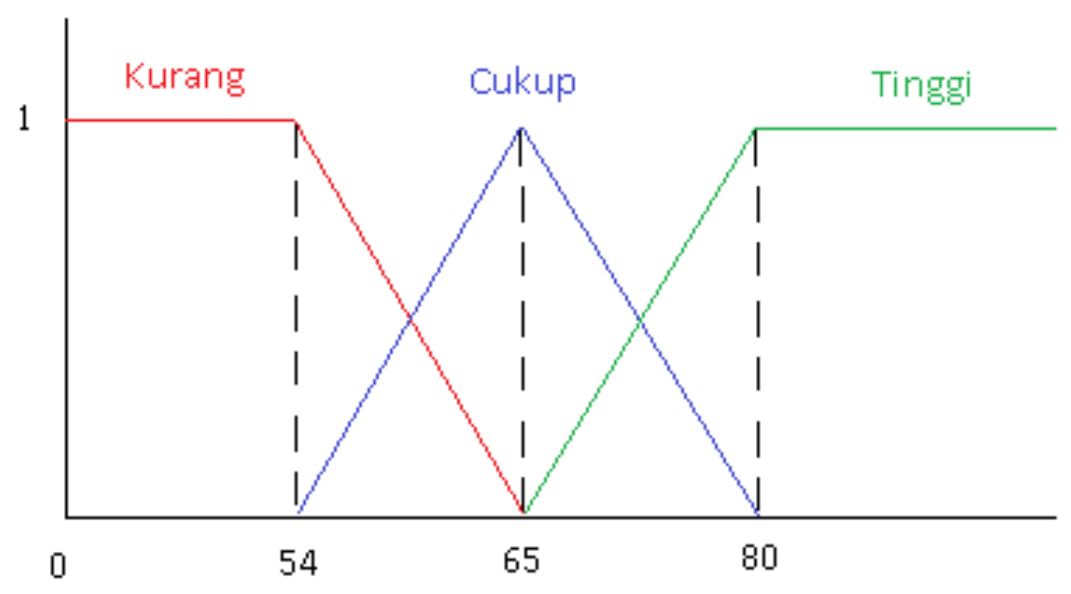

Gambar 9. Grafik Fungsi Keanggotaan Penghasilan Kotor

Fungsi keanggotaan:

$$
\begin{aligned}
& \mu \text { Kurang }[\mathrm{x}]=\left\{\begin{array}{rc}
\frac{65-x}{65-54}, & x \leq 54 \\
0, & x \geq 65
\end{array}\right\} \\
& \mu \text { Cukup }[\mathrm{x}]=\left\{\begin{array}{rc}
0, & x<65 \\
\frac{x-65}{80-65}, & 65<x<80 \\
1, & x \geq 80
\end{array}\right. \\
& \mu \text { Tinggi }[\mathrm{x}]=\left\{\begin{aligned}
\frac{x-65}{05}, & x<65 \\
80-65, & 65<x<80 \\
1, & x \geq 80
\end{aligned}\right.
\end{aligned}
$$


Tabel 4. Pengelompokan Prestasi non Akademik

$\begin{array}{cc}\text { Semesta } & \text { Himpunan Fuzzy } \\ \text { Pembicaraan } & \text { Domain } \\ \text { Nilai }\end{array}$

\begin{tabular}{lcc}
\hline $\begin{array}{l}\text { Prestasi non } \\
\text { akademik }\end{array}$ & Reguler & $0-65$ \\
& Nasional & $54-80$ \\
& Internasional & $65-100$
\end{tabular}

Fungsi keanggotaan untuk variabel prestasi non akademik terdiri dari tiga himpunan fuzzy yaitu Reguler, Nasional, dan Internasional yang diambarkan dalam

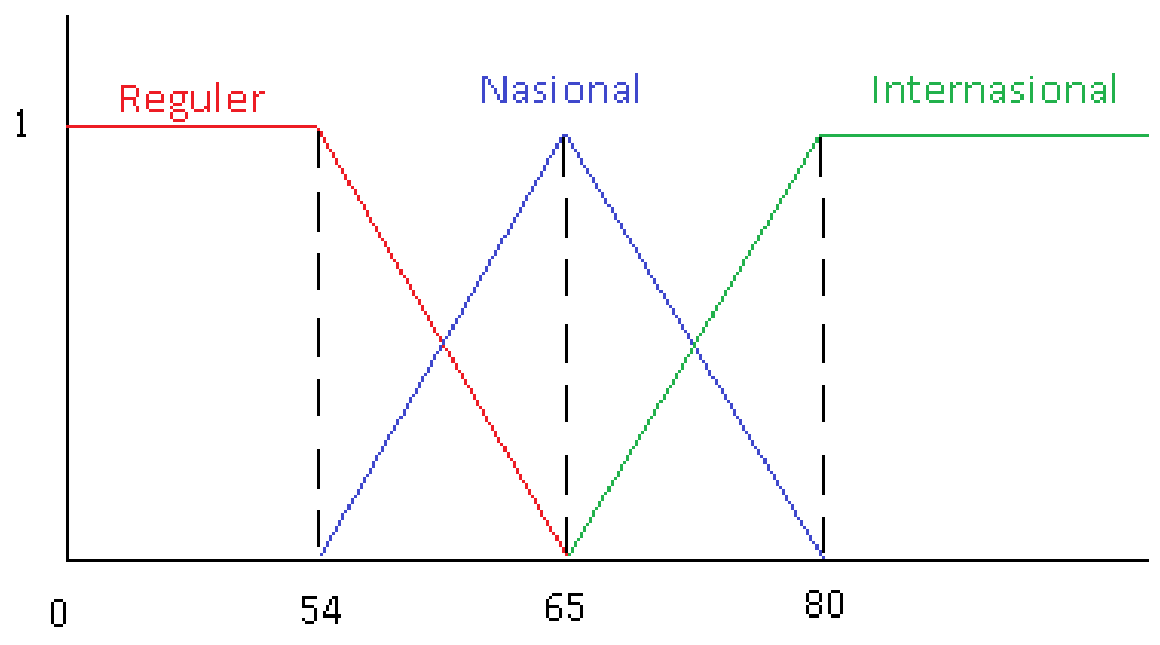

Gambar 10. Grafik Fungsi Keanggotaan Prestasi non Akademik

kurva segitiga sebagai berikut:

Fungsi keanggotaan:

$\mu$ Reguler $[\mathrm{x}]=\left\{\begin{aligned} 1, & x \leq 54 \\ \frac{65-x}{65-54}, & 54<x<65 \\ 0, & x \geq 65\end{aligned}\right.$
$\mu$ Nasional $[\mathrm{x}]=\left\{\begin{array}{rr}0, & x<65 \\ \frac{x-65}{80-65}, & 65<x<80 \\ 1, & x \geq 80 \\ 0, & x<65\end{array}\right.$
$\mu$ Internasiona $[\mathrm{x}]=\left\{\begin{array}{rc}\frac{x-65}{80-65}, & 65<x<80 \\ 1, & x \geq 80\end{array}\right.$ 


\section{Hasil Penelitian dan Pembahasan}

Bab ini merupakan hasil dan pembahasan sistem penerapan metode fuzzy dalam menentukan mahasiswa yang berhak menerima beasiswa. Proses melakukan identifikasi dilakukan dengan melaksanakan penelitian dan observasi pada sistem yang sedang berjalan. Hasil penelitian-penelitian tersebut dipergunakan untuk masukan ke dalam sistem yang akan dikembangkan.

\section{A. Antar Muka Pengguna}

Antar muka pengguna digunakan untuk memudahkan user dalam melakukan operasi perhitungan. Pada antar muka ini akan dijabarkan di beberapa bagian yang akan digunakan oleh user.

\section{Halaman Utama}

Pada halaman utama terdapat tulisan selamat datang di sistem pendukung keputusan dalam menentukan beasiswa berprestasi menggunakan metode fuzzy. Terdapat juga menu input data siswa dimana user dapat menginputkan nilai dari kriteria yang telah ditentukan oleh admin. Selain itu juga terdapat menu parameter fuzzy, fuzzifikasi IPK, fuzzifikasi penghasilan kotor, fuzzifikasi prestasi non akademik, defuzzifikasi, dan kontak.
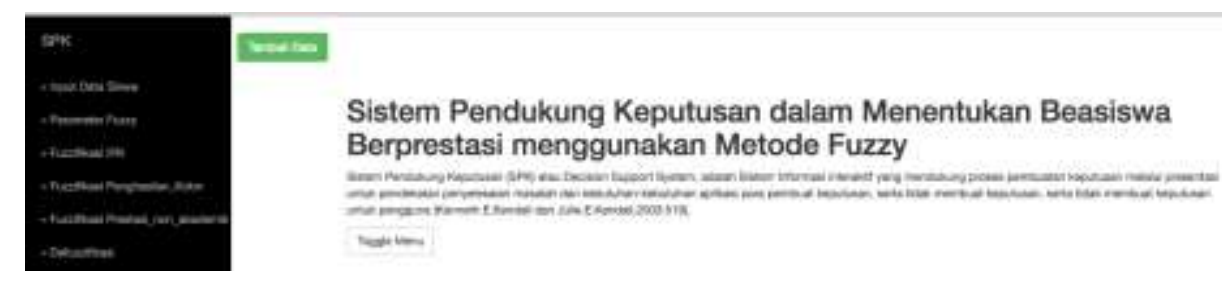

Gambar 11. Antarmuka Halaman Utama

\section{Halaman Masukkan Data Siswa}

Pada halaman ini digunakan user untuk memasukkan nilai untuk masing-masing kriteria.

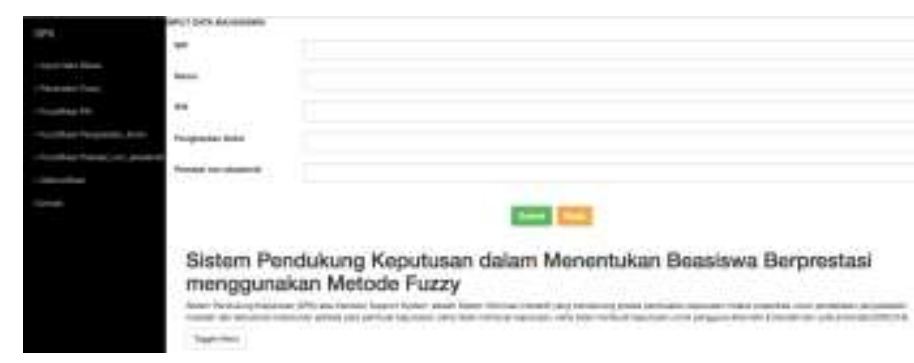

Gambar 12. Halaman Masukkan Data Siswa 


\section{Halaman Fuzzifikasi IPK}

Pada halaman fuzzifikasi IPK menampilkan penerima beasiswa berdasarkan IPK dengan derajat keanggotaannya pada setiap himpunan. Hasil dari derajat keanggotaan didapat setelah diproses dengan ekspresi fungsi keanggotaan fuzzy variabel IPK.
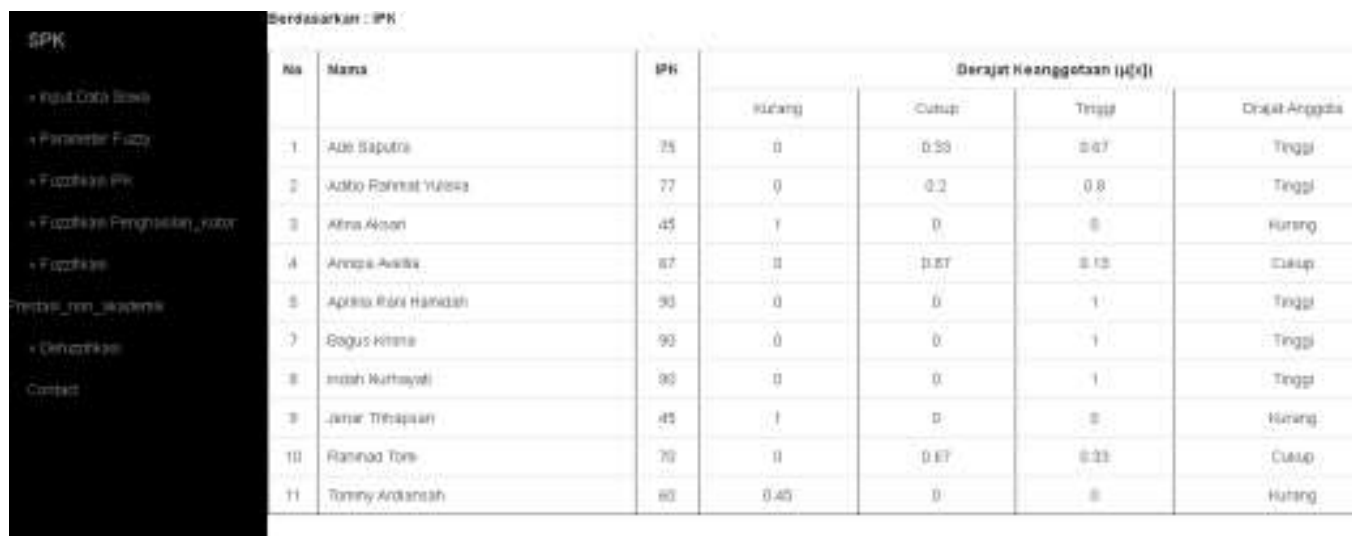

Gambar 13. Halaman Fuzzifikasi IPK

\section{Halaman Fuzzifikasi Penghasilan Kotor Orangtua}

Pada halaman fuzzifikasi penghasilan kotor orang tua menampilkan penerima beasiswa berdasarkan penghasilan kotor orangtua dengan derajat keanggotaannya pada setiap himpunan. Hasil dari derajat keanggotaan didapat setelah diproses dengan ekspresi fungsi keanggotaan fuzzy variabel penghasilan kotor orang tua.

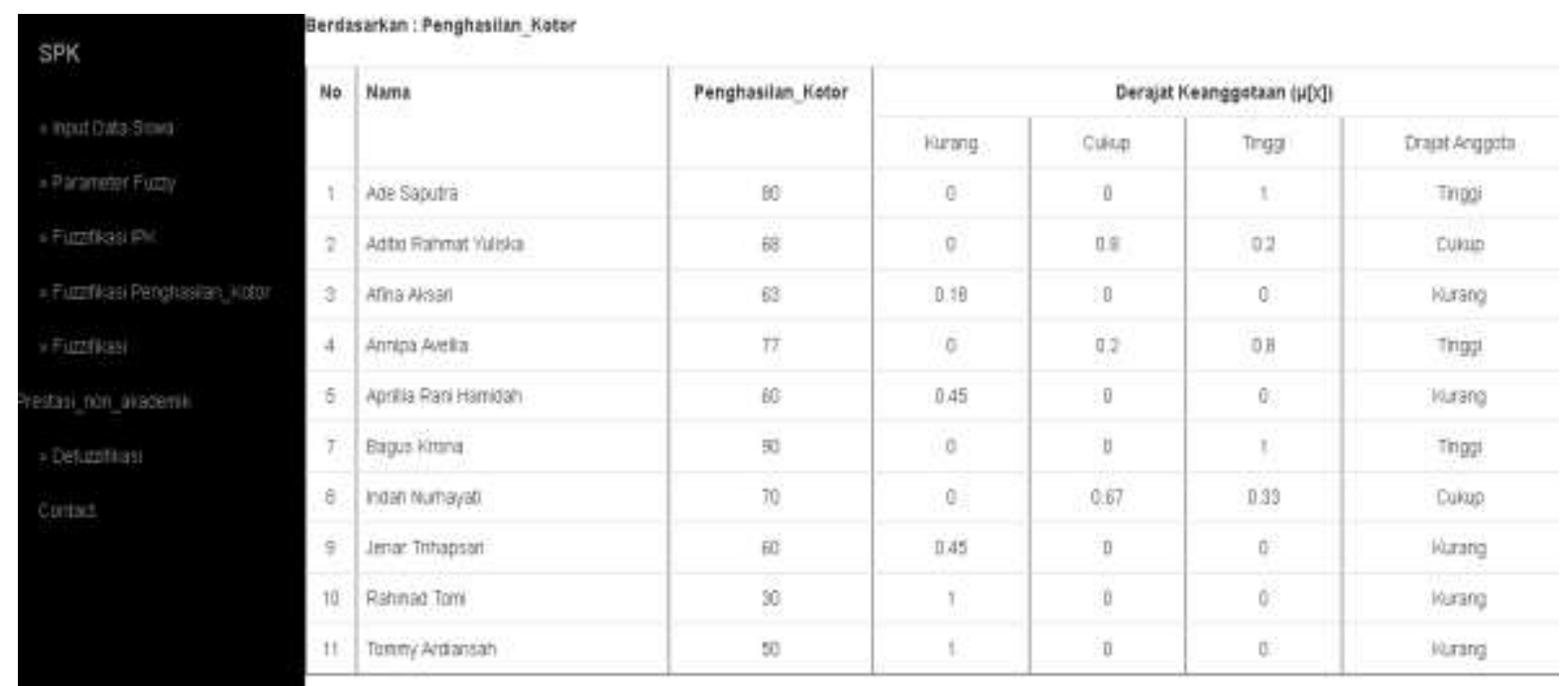

Gambar 14. Halaman Fuzzifikasi Penghasilan Kotor 


\section{Halaman Fuzzifikasi Prestasi non Akademik}

Pada halaman fuzzifikasi prestasi non akademik menampilkan penerima beasiswa berdasarkan prestasi non akademik dengan derajat keanggotaannya pada setiap himpunan. Hasil dari derajat keanggotaan didapat setelah diproses dengan ekspresi fungsi keanggotaan fuzzy variabel prestasi non akademik
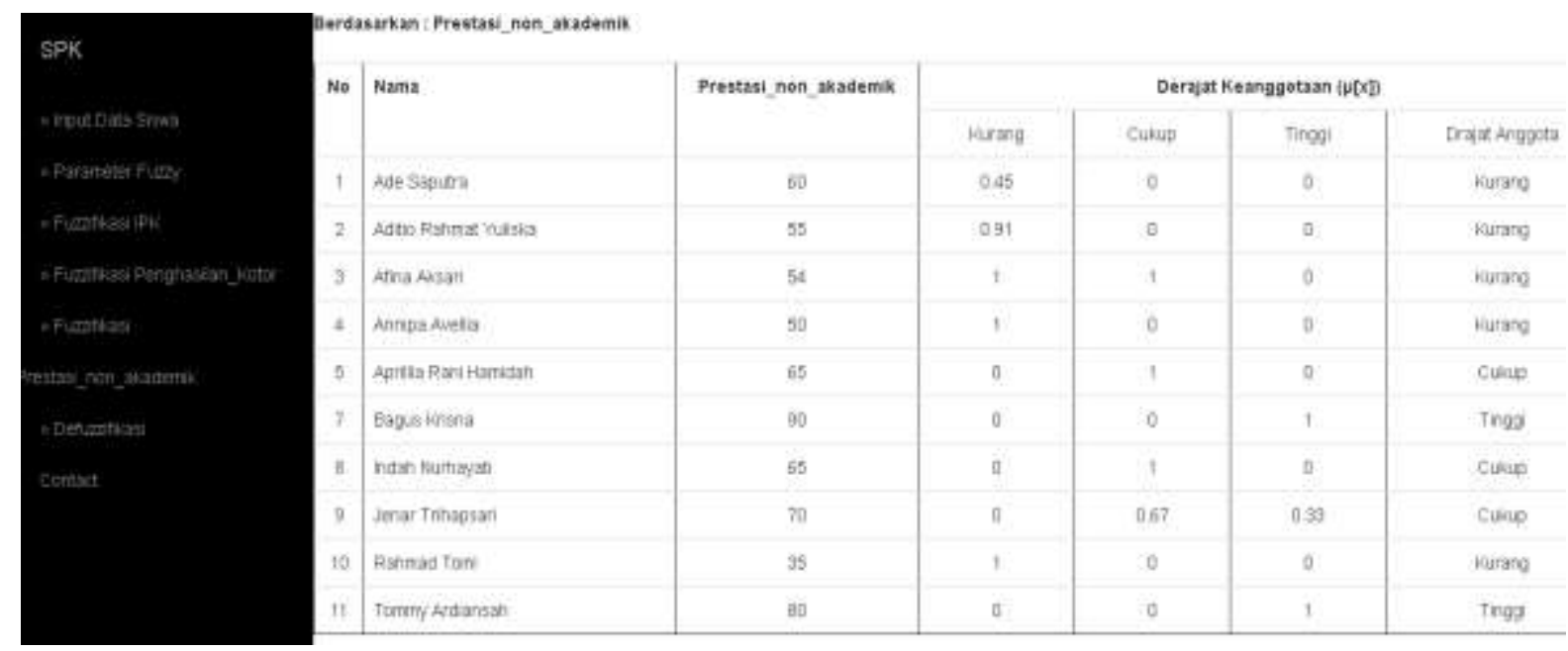

Gambar 15. Halaman Fuzzifikasi Prestasi non Akademik

\section{Halaman Deffuzifikasi}

Halaman ini menampilkan hasil perhitungan defuzzifikasi dengan keluaran berupa rekomendasi nama mahasiswa yang berhak mendapatkan beasiswa.

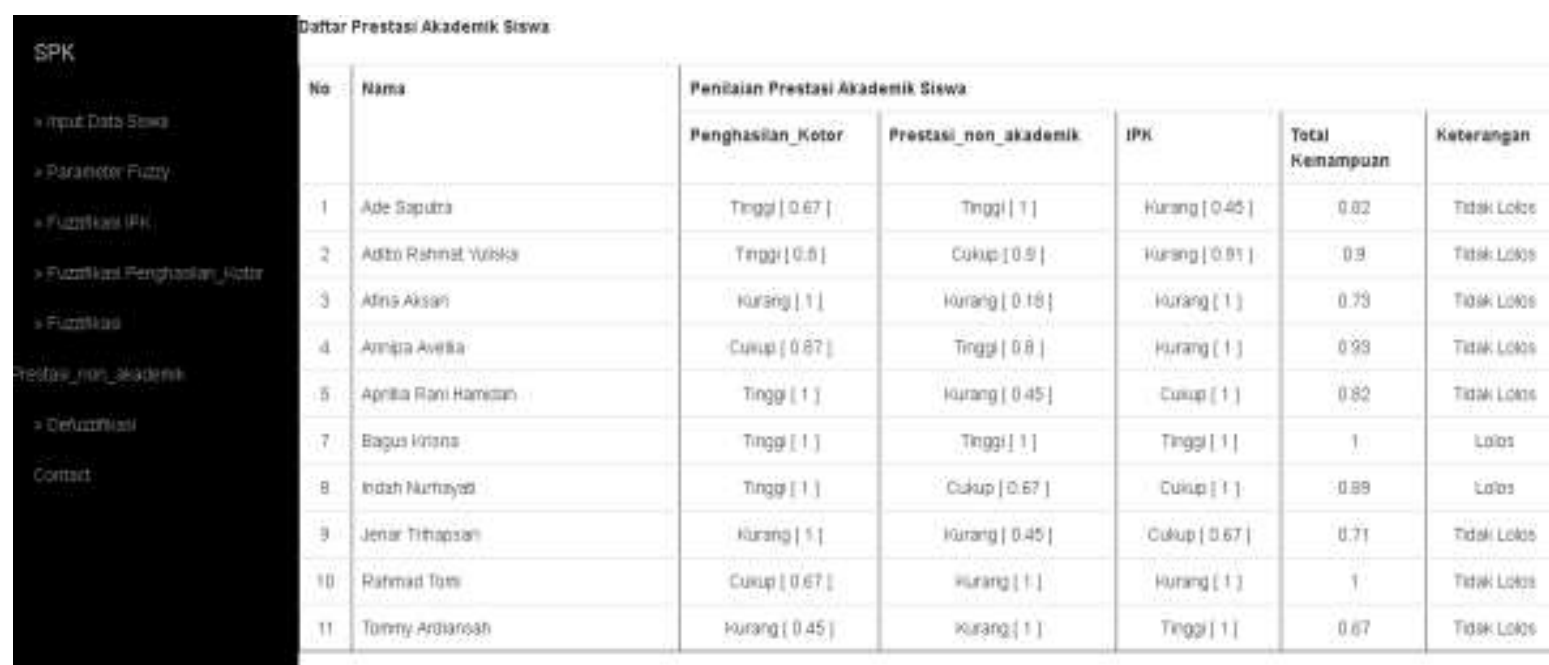

Gambar 16. Halaman Deffuzifikasi 


\section{B. Pengujian}

Untuk mendapatkan hasil yang maksimal maka perlu adanya pengujian pada sisi aplikasi dengan memasukkan nilai pada halaman masukkan data mahasiswa. User menginputkan nilai dengan mengklik pada tiap-tiap kotak yang tersedia sehingga akan

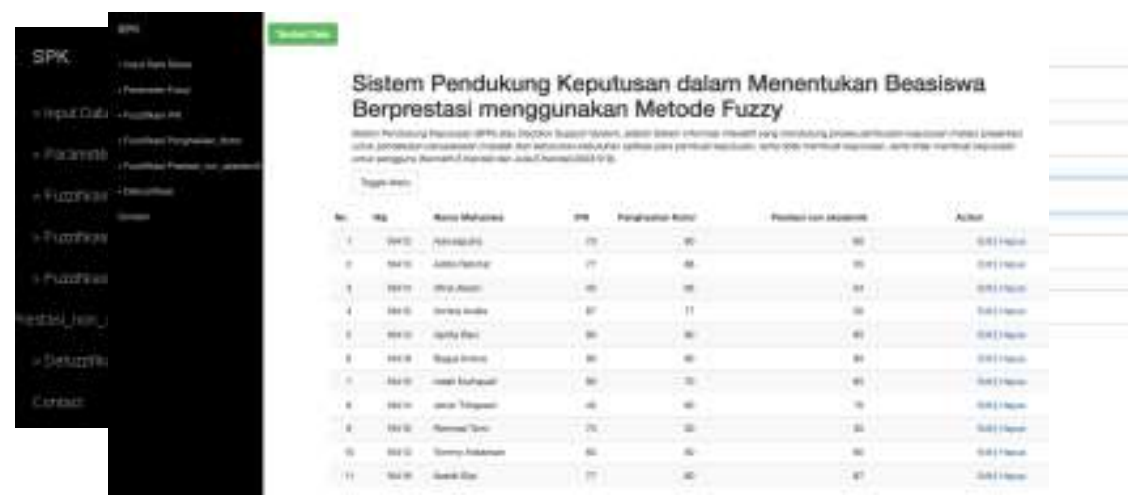

Gambar 18. Pengujian Halaman Setelah Masukkan Data

muncul halaman input nilai pada Gambar 17.

Jika user telah berhasil memasukkan nilai maka nilai-nilai yang telah diinputkan akan tampil pada halaman awal (Gambar 18). Pada halaman user selain menampilkan nilai-nilai yang telah diinput oleh user, terdapat hasil fuzzifikasi IPK, penghasilan kotor orang tua dan prestasi non akademik. Untuk melihat hasil akhir dari perhitungan maka user melakukan langkah berikutnya yaitu dengan menekan tombol deffuzifikasi.

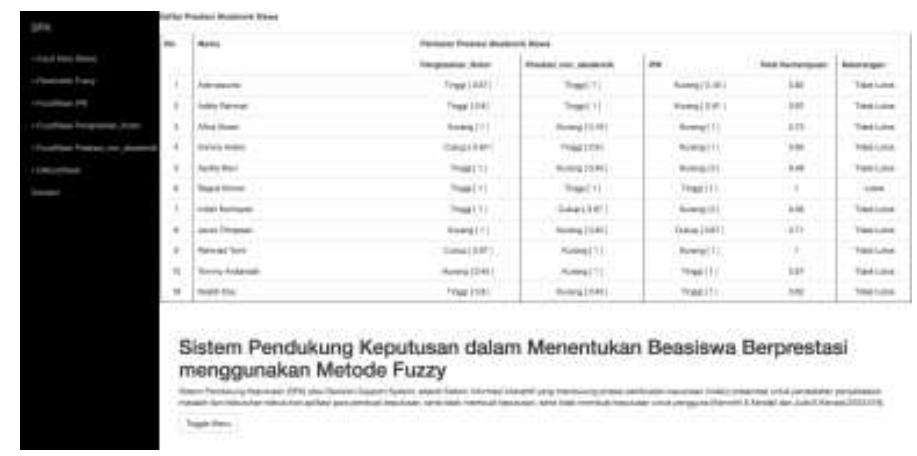

Gambar 19. Halaman Deffuzifikasi 
Pada halaman akhir user dapat mengetahui rekomendasi penerima beasiswa. Untuk menguji sistem maka akan diberikan kasus untuk penyeleksian beasiswa dengan ketentuan tidak terdapatnya nilai yang kurang. Pada aplikasi terlihat hasil bahwa yang lolos adalah mahasiswa yang tidak terdapat nilai yang kurang. Hal ini terlihat pada

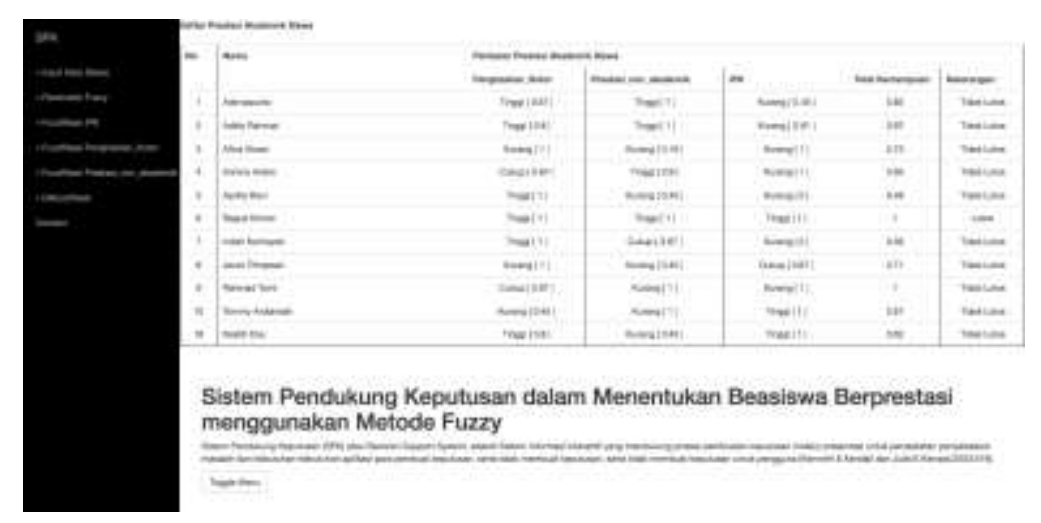

Gambar 20. Pengujian Aplikasi

Gambar 20.

\section{KESIMPULAN DAN SARAN}

\section{A. Kesimpulan}

Dari hasil penelitian yang dilakukan maka dapat diambil kesimpulan sebagai berikut logika fuzzy dapat diterapkan untuk menentukan mahasiswa yang berhak mendapatkan beasiswa dengan menggunakan nilai kriteria seleksi beasiswa sebagai data input fuzzy. Dengan logika fuzzy proses penyeleksian menjadi lebih adil dan akurat dengan memperhatikan nilai yang proporsional bagi setiap kriteria perekrutannya. Logika fuzzy dapat dijadikan sebagai alat bantu pendukung keputusan dalam melakukan proses seleksi penerima beasiswa.

\section{B. Saran}

1) Dapat dilakukan penambahan variabel.

2) Dalam perhitungan solusi dengan menggunakan model fuzzy, dapat memperbanyak pilihan kriteria yang diajukan sistem yang bersifat dinamik, yang terdiri dari variabel input fuzzy dan variabel input non fuzzy.

\section{Daftar Pustaka}

Cristiono, Denny, 2005, Aplikasi Pendukung Keputusan Dengan Menggunakan Logika Fuzzy (studi kasus Pemilihan Handphone Berdasarkan Kebutuhan Konsumen), Salatiga, Fakultas Teknologi Informasi, Universitas Kristen Satya Wacana. 
Kusumadewi, Sri. 2007. Sistem Fuzzy Untuk Klasifikasi Indikator Kesehatan Daerah. Yogyakarta. ISSN: 978-979-96964-5-8.

Kusumadewi, Sri \& Hari Purnomo. 2010. Aplikasi Logika Fuzzy Untuk Pendukung Keputusan Edisi Kedua. Yogyakarta: Graha Ilmu.

Kusrini, Konsep dan Aplikasi Sistem Pendukung Keputusan. Yogyakarta : Penerbit ANDI, 2007.

Turban, Efraim, 2005, Sistem Pendukung Keputusan dan Sistem Cerdas, Andi, Yogyakarta.

Yudanto, A.Y, Apriyadi, M dan Sanjaya, K. Optimalisasi Lampu Lalu Lintas dengan Fuzzy Logic, ULTIMATICS,Vol V, No.2 | Desember 2013 